\title{
ESHG warns against misuses of genetic tests and biobanks for discrimination purposes
}

\author{
Francesca Forzano ${ }^{1} \cdot$ Maurizio Genuardi $\mathbb{1}^{2,3} \cdot$ Yves Moreau $^{4} \cdot$ On behalf of the European Society of Human \\ Genetics
}

Received: 17 November 2020 / Accepted: 19 November 2020 / Published online: 18 January 2021

(c) The Author(s), under exclusive licence to European Society of Human Genetics 2021

Medical knowledge is a powerful instrument that is meant for individual and collective good. Since the time of Hippocrates, we have known it should never be abused, even if serious misuses have occurred in modern history. Among the most recent examples of harm is the compulsory collection of DNA samples from ordinary people being carried out by the Chinese authorities in Xinjiang province as part of a programme of surveillance and control [1]. As members of ESHG, professionals working in genetics and genomics, we feel that we must point out the damage that such a collection may cause: first to those directly affected, but also to the reputation of academic and healthcare institutions (including ethics committees), companies and publishers, and the image of genetics in the wider world. Such abuses of genetic tests and DNA collection may damage the trust citizens put into genetics and the promise of personalised medicine, and thus could impair the future of genetic research and healthcare overall.

The recent announcement by Springer Nature of the retraction of a 2019 paper [2] on Y-chromosome profiling of ethnic minorities in China and of another on InDel profiling [3], and the placing under scrutiny of more than two dozen others for similar concerns, is an important step in the right direction. However, it still appears that almost half of over a thousand articles describing forensic genetics studies in Chinese populations have at least one co-author from the Chinese police, judiciary or related institutions. It is

Francesca Forzano

francesca.forzano@nhs.net

1 Department of Clinical Genetics, Guy's and St Thomas NHS Foundation Trust and King's College London, London, UK

2 Fondazione Policlinico Universitario IRCCS, Rome, Italy

3 Dipartimento di Scienze della Vita e Sanità Pubblica, Università Cattolica del Sacro Cuore, Rome, Italy

4 ESAT-STADIUS, KU Leuven - University of Leuven, Leuven, Belgium impossible to carry out forensic population genetics research in China independently from the Chinese authorities. All this literature is thus potentially ethically tainted.

Publishers correctly require that the studies described in submitted manuscripts have ethical approvals. However, they may fail to recognise that some ethics committees may not function or abide by expected ethical standards. For example, multiple studies have been approved by ethics committees run by the Chinese Ministries of Public Security or Justice. In the retracted study on InDel markers, the investigation revealed that out of four Chinese populations, ethical approval had only been obtained for the Han majority group. Publishers should conduct a mass reassessment of this literature and require further information on consent and ethical approvals in addition to considering whether the studies fulfil the basic ethical requirements for non-maleficence, beneficence, justice and veracity. Such an assessment would be important if, in the future, any doubt arises about the data and the uses to which they may be put.

These problems extend beyond China. For example, the Ychromosome haplotype reference database (YHRD), hosted by the Charité University of Berlin, contains over 12,000 forensic Y-chromosome profiles from vulnerable Chinese populations [4]. The YHRD also contains considerable multiple data sets on Roma people, and their over-representation in the database is significant. For example, among 600 Y-chromosome profiles from Bulgaria, 311 are from Roma individuals [5]. We would like to see an end to collaborations between academic and clinical institutions worldwide and institutions in countries carrying out widespread, unethical DNA collections and/or analysis, and any databases containing such material destroyed, or have any ethically problematic data removed. We would encourage institutions to carry out regular reassessments of such databases, following an initial assessment that considers the risk of potential abuse and provides guidance on how it may be avoided.

We suggest that companies, too, should stop sales to the institutions involved in ethically tainted genetic research. 
One of the largest companies serving the area, Thermo Fisher Scientific, has decided to stop sales of equipment to Xinjiang police forces, but such action by one company alone is insufficient to tackle the problem. The retracted Ychromosome study on vulnerable Xinjiang minorities involved authors from the Xinjiang police forces and used Thermo Fisher products. The only effective way would seem to be to stop sales to police and judiciary forces across China of products used in the identification of humans by means of molecular genetics. Other Western suppliers, such as Promega and QIAGEN, should follow suit.

The US Government has imposed Magnitsky sanctions on the Xinjiang public security authorities for human rights abuses [6]. This means that American citizens and companies are forbidden to interact with them. However, the US Government itself has been carrying out a compulsory DNA profiling on migrants crossing the border with Mexico. These data will be lodged with the FBI, even though the sole offence the individual may have committed is an attempt to enter the country illegally. The problem of the unethical collection of DNA samples is clearly not limited to China.

Another recent example comes from Kuwait, where, in 2015, the government became the first in the world to introduce a law requiring the compulsory collection of DNA samples from all citizens, residents and visitors to the country. Such a measure was introduced purportedly to discourage terrorism, but many suspected that it could lead to genetic discrimination against some vulnerable minorities. The following year, after an international campaign against the measure, led by European geneticists and a courageous Kuwaiti lawyer, the law was dropped [7].

In Thailand, the compulsory collection of DNA came into force in the south of the country in 2015 as part of an attempt to curb insurgency by Muslim Malay rebels [8]. In that year alone, samples were taken from more than 40,000 people, according to a local police chief. More recently, DNA collection has become a part of the military conscription process for men residing in the southern provinces of Thailand [9]. Although they were asked to sign a consent form, the men reported that they were given no information as to the proposed use of their DNA or the duration of storage of their DNA samples, nor were they told that it was legal to refuse consent. Products from Thermo Fisher Scientific, QIAGEN and Promega appear to be used by the Thai police force.

While China, the USA and Thailand are very different countries from Kuwait, both in their size and their leadership, the Kuwaiti example gives us reason to hope that international pressure may have an effect. We are concerned that the growing public awareness of abusive DNA collections will have a detrimental effect on the image of genetics in the wider world. The anti-vaccination movement started off small and was supported by only a handful of mavericks. Few people would have imagined that it would grow so quickly, and to such an extent that a substantial proportion of the population in many Western countries refrain from vaccinations, depriving their children of potentially life-saving tools, and also suggesting they might refuse to be vaccinated against COVID-19.

Likewise, if awareness of the coercive nature of the collection of some human DNA samples becomes widespread, whether through accurate reporting or via conspiracy theories on social media, it may affect people's willingness to donate samples voluntarily and to contribute to the research and diagnostic databases that are so important in the quest for improving and advancing medical knowledge and the treatment of diseases. As an example, Hong Kong activists have reasonable concerns about a possible diversion of biological samples for COVID-19 testing to forensic DNA profiling, and this has led to calls for the avoidance of such testing.

Article 7 of the International Declaration on Human Genetic Data (UNESCO, IBC 2003) states:

"Non-discrimination and non-stigmatization

(a) Every effort should be made to ensure that human genetic data and human proteomic data are not used for purposes that discriminate in a way that is intended to infringe, or has the effect of infringing human rights, fundamental freedoms or human dignity of an individual or for purposes that lead to the stigmatization of an individual, a family, a group or communities.

(b) In this regard, appropriate attention should be paid to the findings of population-based genetic studies and behavioural genetic studies and their interpretations".

We can and must keep up the pressure to ensure that the most basic rights to privacy and bodily integrity are respected across the world. In this time of COVID-19, Chinese science is increasingly under scrutiny from all quarters. The country's reaction to the pandemic has been widely praised. It is surely not in their interest to damage their standing in the scientific world by continuing with what are clearly unethical and discriminatory practices.

Acknowledgements We are indebted to Mary Rice for her help in preparing this paper. The paper has been revised with the contribution of members of the Executive Board and the Public and Professional Policy Committee (PPPC) of the European Society of Human Genetics (ESHG). Members of the PPPC in 2020 were: Angus Clarke, Martina Cornel (Co-Chair), Carla van El (Secretary General), Christophe Cordier, Florence Fellmann, Francesca Forzano (Chair), Sabine Hentze, Heidi Howard, Hülya Kayserili, Milan Macek Jr, Béla Melegh, Alvaro Mendes, Markus Perola, Inga Prokopenko, Dragica Radojkovic, Emmanuelle Rial-Sebbag, Vigdis Stefánsdottir and Guido de Wert. Fiona Ulph was a PPPC collaborator in 2020. Members of the Executive Board in 2020 were: Prof. Alexandre Reymond, Prof. Maurizio Genuardi, Prof. Gunnar Houge, Prof. Karin Writzl, Prof. Carla Oliveira and Prof. Andrew Read. 


\section{Compliance with ethical standards}

Conflict of interest The authors declare that they have no conflict of interest.

Publisher's note Springer Nature remains neutral with regard to jurisdictional claims in published maps and institutional affiliations.

\section{References}

1. Human Rights Watch. China: minority region collects DNA from millions. 2017. https://www.hrw.org/news/2017/12/13/china-minorityregion-collects-dna-millions.

2. Zhang D, Cao G, Xie M, Cui X, Xiao L, Tian C, et al. RETRACTED ARTICLE: Y Chromosomal STR haplotypes in Chinese Uyghur, Kazakh and Hui ethnic groups and genetic features of DYS448 null allele and DYS19 duplicated allele. Int J Legal Med. 2019.

3. Pan X, Liu C, Du W, Chen L, Han X, Yang X, et al. RETRACTED ARTICLE: Genetic analysis and forensic evaluation of 47 autosomal InDel markers in four different Chinese populations. Int $\mathrm{J}$ Legal Med. 2020;134:2079.
4. Willuweit S, Roewer L. The Y-Chromosome Haplotype Reference Database (YHRD): Information on the national database 'China'. 2020. https://web.archive.org/web/20200930214503/https://yhrd. org/tools/national_database/China.

5. Berndt C. Falscher Verdacht. Süddeutsche Zeitung. 2020. https://www.sueddeutsche.de/wissen/sinti-roma-genetik-verdacht1.5114089 !amp.

6. US Department of the Treasury. Treasury Sanctions Chinese Entity and Officials Pursuant to Global Magnitsky Human Rights Executive Order. 2020. https://home.treasury.gov/news/press-relea ses/sm1073.

7. Coghlan A. Kuwait to change law forcing all citizens to provide DNA samples. New Scientist. 2016. https://www.newscientist. com/article/2109959-kuwait-to-change-law-forcing-all-citizens-toprovide-dna-samples/.

8. Lefevre AS. Thailand's new weapon to beat deep-south insurgencyDNA swabs. Reuters. 2015. https://uk.reuters.com/article/uk-thailandsouth-dna/thailands-new-weapon-to-beat-deep-south-insurgency-dnaswabs-idUKKBNONR2FN20150506.

9. Benjakat A. Conscripts' DNA records being added to security database. Bangkok Post. 2019. https://www.bangkokpost.com/tha iland/general/1657204/conscripts-dna-records-being-added-tosecurity-database. 